Original Article

\title{
Influence of urbanization on stream fish assemblages in three microbasins in the Upper Paraná River Basin
}

\author{
Influência da urbanização em assembleias de peixes de riachos em três microbacias na \\ bacia do Alto Rio Paraná
}

\author{
F. S. Ferreira ${ }^{\mathrm{a} *}$ (D) J. C. J. Solórzano ${ }^{\mathrm{a}}$ (1) and Y. R. Súarez ${ }^{\mathrm{a}, \mathrm{b}}$ (D) \\ anniversidade Estadual de Mato Grosso do Sul - UEMS, Programa de Pós-graduação em Recursos Naturais - PGRN, Dourados, MS, Brasil \\ bUniversidade Estadual do Mato Grosso do Sul - UEMS, Centro de Estudos em Recursos Naturais - CERNA, Laboratório de Ecologia, Dourados, \\ MS, Brasil
}

\begin{abstract}
The colonization pattern of fish assemblages in streams is often studied in the context of environmental filters. On the other hand, when fish assemblages are subjected to anthropogenic effects, variables associated with environmental quality assume more importance. Therefore, this work evaluated the richness and composition of fish from streams sampled at different urbanization levels, aiming to determine any direct effects on the structure of fish assemblages. To accomplish this, samples were collected from 2003 to 2011 at 31 sites distributed among 3 microbasins in the Rio Ivinhema Basin, Alto Rio Paraná. Based on environmental variables, physicochemical of the water and analysis of the use and occupation of the soil, the microbasins were classified into different urbanization levels (low, medium and high). A total of 4,320 individuals were sampled, out of which 57 fish species were recorded. Sampled sites with medium urbanization level presented higher richness compared to sampled sites with high urbanization level which presented lower richness. Species richness in these sites was explained mainly by water temperature and water velocity. Results confirmed that urbanization does directly affect environmental integrity, which, in turn, can lead to the homogenization of stream assemblages.
\end{abstract}

Keywords: environmental gradient, species richness, fish assemblages, anthropogenic influence.

\section{Resumo}

Estudos sobre assembleias de peixes em riachos enfatizam o papel dos filtros ambientais associados ao padrão de colonização das assembleias, por outro lado, quando a assembleia está sujeita aos efeitos antropogênicos, as variáveis ambientais associadas à qualidade ambiental assumem maior importância. Dessa forma, o objetivo deste estudo foi analisar a riqueza e a composição de peixes de riachos amostrados em diferentes níveis de urbanização, buscando evidenciar se o efeito reflete diretamente na estrutura das assembleias. As amostragens foram realizadas em 31 locais distribuídos em três microbacias na bacia Rio Ivinhema, Alto Rio Paraná, no período de 2003 a 2011. Com base nas variáveis ambientais, físico-químicos da água e análise do uso e ocupação do solo as microbacias foram classificadas em diferentes níveis de urbanização (baixo, médio e alto). Foram amostrados um total 4.320 indivíduos, dos quais foram registradas 57 espécies de peixes. Os locais amostrados com influência média da urbanização apresentaram maior riqueza de espécies, entretanto, os locais amostrados com alta influência da urbanização apresentaram menor riqueza de espécies. Dessa forma, constatamos que a urbanização influencia diretamente na integridade ambiental, que pode levar a homogeneização das assembleias de riachos.

Palavras-chave: gradiente ambiental, riqueza de espécies, assembleias de peixes, influência antrópica.

\section{Introduction}

Local communities are influenced by habitat characteristics, as well as biotic and environmental factors (Hoeinghaus et al., 2006). The importance of these factors in shaping species distribution, abundance (Hoeinghaus et al., 2006) and richness (Johnson et al., 2004) often depends on the spatial scale analyzed (Jackson et al., 2001). Other important determinants of species richness are environmental features, such as channel morphology (Schlosser, 1982), water depth, substrate type, water velocity, vegetation cover (Teresa and Casatti, 2010), and characteristics of the water, such as nutrient concentrations and dissolved oxygen content (Honnen et al., 2001).

Many stream ecosystems have experienced environmental changes caused mainly by land use, such as urban expansion (Chaudhary et al., 2018; McDonald et al., 2020) and subsequent increase in human activities in stream

*e-mail: fabianesfbio@gmail.com

Received: January 8, 2021 - Accepted: March 17, 2021 
areas, e.g., damming, replacement of native vegetation by crops or livestock, introduction of exotic species, and pollution (Mckinney, 2006). These anthropogenic factors change species composition, potentially affecting diversity (Cunico et al., 2012). Biotic and abiotic factors also influence the abundance and distribution of fish in impacted streams (Paul and Meyer, 2001) owing to various environmental changes (Alexandre et al., 2010; Daga et al., 2012; Peressin and Cetra, 2014).

These disturbances triggered by urbanization not only destroy the habitats of native species, but they also modify habitats where only a few well-adapted species can live. This can set the stage for the replacement of native species by non-native species, a process which can promote biotic homogenization at multiple spatial scales (Olden and Poff, 2003; McKinney, 2006). However, while a major consequence of conservation, along with biotic homogenization, is an enrichment of local diversity through the introduction of non-native species (Mckinney, 2006), a decrease in regional or global diversity from local extinctions can also occur (Mckinney, 2006). Despite conservation efforts, biodiversity losses continue at regional and global scales as a result of the increased intensity of human disturbance. This calls for a better understanding of such disturbances and their effect on the patterns of diversity in areas containing natural resources, such as streams (Mouillot et al., 2012).

In this study, we hypothesized that streams under greater influence of urbanization would exhibit correspondingly greater alteration in habitat conditions, resulting in lower richness and homogenization when compared to streams less affected by urbanization. Overall, we aimed to evaluate the effects of urbanization on patterns of organization in these stream fish assemblages.

\section{Methods and Materials}

\subsection{Study area}

The Ivinhema River Basin is located in the Upper Paraná River in the state of Mato Grosso do Sul in central Brazil. The Ivinhema River is formed by convergence of the Dourados, Brilhante and Vacaria Rivers. Stretching approximately $600 \mathrm{~km}$ with an area of $45,000 \mathrm{~km}^{2}$, this basin is one of few remaining segments with lotic (i.e., without the influence of damming) characteristics in the Upper Paraná River Basin (Súarez et al., 2011). Samples were collected from 2003 to 2011 along 31 stream sites at Curral de Arame, Laranja Doce and Água Boa microbasins (Figure 1).

\subsection{Fish sampling}

Fish were sampled from an extension of each stream of approximately $100 \mathrm{~m}$, predominantly using a $1.2 \times 0.8 \mathrm{~m}$ ( $2 \mathrm{~mm}$ mesh size) rectangular sieve. Larger streams were sampled also, using a seine net $1.5 \times 5 \mathrm{~m}$ ( $2 \mathrm{~mm}$ mesh size) and gillnets (15, 20, 30, 40 and $50 \mathrm{~mm}$ mesh size) between adjacent knots. In the field, all fish were anesthetized with clove oil and later fixed in $10 \%$ formalin. In the laboratory, after at least 72 hours, fish were preserved in $70 \%$ ethanol
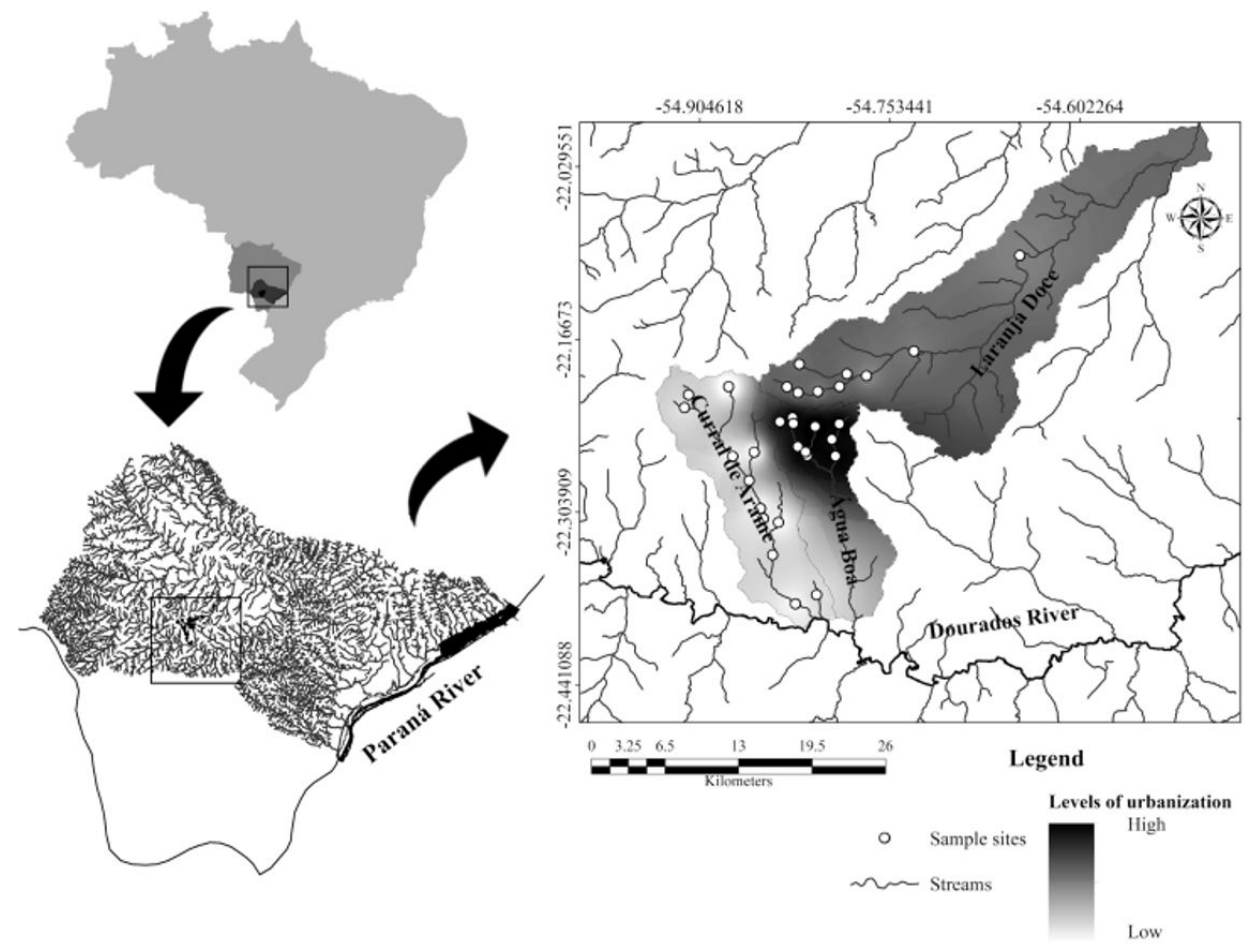

Figure 1. Location of streams sampled among the different urbanization levels (low, medium, and high) in the Ivinhema River Basin, Upper Paraná River Basin, from 2003 to 2011. 
for subsequent identification. Specimens were identified in the laboratory using a taxonomic key by Graça and Pavanelli (2007), as well as consultations with specialists from the Núcleo de Pesquisa em Limnologia, Ictiologia e Aquicultura (Nupélia-UEM).

In the field, all streams were measured for environmental variables and physicochemical of the water, such as $\mathrm{pH}$, conductivity $\left(\mu \mathrm{S} / \mathrm{cm}^{-1}\right)$, water temperature $\left({ }^{\circ} \mathrm{C}\right)$, dissolved oxygen (\% saturation), water velocity $(\mathrm{m} / \mathrm{s})$, stream width $(\mathrm{m})$, and stream depth $(\mathrm{m})$ (Table 1$)$.

\subsection{Analysis of land use and cover}

Land use and cover were mapped based on Landsat Images with a pixel size (cell) of 30x30 obtained from the United States Geological Survey (USGS). For delimitation microbasins were created using Digital Elevation Models (DEM) obtained from the USGS site. Land use was classified as agricultural, forest fragments, water bodies, and urban buildings (Table 2). To interpret the images, a supervised classification was used with tools provided by the ArcGIS $10.4{ }^{\circledR}$ program in the trial version (ESRI, 2015), calculating the areas and percentages of each category of land use.

\subsection{Environmental gradient}

The environmental gradient along the analyzed microbasins was categorized by urbanization level, as influenced by environmental variables (Table 1 ) and local characteristics of land use and cover (Table 2). The microbasins were classified as low (Curral de Arame - CA), medium (Laranja Doce - LD), and high (Água Boa AB) urbanization level.
With its $5.5 \%$ of urbanized areas and $29.7 \%$ of forest fragments, as well as sites with higher oxygen concentration and lower water conductivity compared to the other microbasins, the Curral de Arame microbasin was classified as the least influenced by urbanization based on its rural location (Tables 1 and 2). The Laranja Doce microbasin was classified as medium, presenting $14.2 \%$ of urbanized areas and $18.2 \%$ of forest fragments, as well as intermediate conductivity values owing to the location of headwaters in an urban portion of Dourados city (Tables 1 and 2). The Água Boa microbasin was classified as high because the headwaters are located in an urban area of Dourados, crossing densely populated suburbs, as well as some agricultural areas around the city, resulting in $29.2 \%$ of urbanized areas and $49.3 \%$ of agriculture, as well as sites with the highest water temperatures and water conductivity values (Tables 1 and 2 ).

\subsection{Data analysis}

The total species richness and the species richness for among the different urbanization levels were estimated using the bootstrap procedure (Smith and Van Belle, 1984), as well as its confidence interval $(\alpha=0.05)$. This procedure was selected for its robustness, with relatively large sample sizes (Hellmann and Fowler, 1999). To visualize differences in the number of species along the number of samples size we plotted a species accumulation curve by urbanization levels. The sites were selected randomly and the cumulative number of species was plotted against each sampling unit by urbanization level.

The number of individuals can affect the number of registered species in a local assemblage sampling, then we estimated a rarefied species richness for each stream

Table 1. Mean values $( \pm$ SD) of environmental descriptors sampled among the different urbanization levels on streams, i.e., low (Curral de Arame microbasin), medium (Laranja Doce microbasin), and high (Água Boa microbasin), in the Ivinhema River Basin, Upper Paraná River Basin.

\begin{tabular}{|c|c|c|c|c|c|c|c|c|}
\hline \multirow{2}{*}{$\begin{array}{c}\text { Urbanization } \\
\text { levels }\end{array}$} & Depth & Veloc. & Cond. & Oxig. & Oxig. & \multirow{2}{*}{ pH } & Temp. & Width \\
\hline & $(\mathrm{m})$ & $(\mathbf{m} / \mathbf{s})$ & $\left(\mu \mathrm{S} / \mathrm{cm}^{-1}\right)$ & $(\mathrm{mg} / \mathrm{l})$ & (\%) & & $\left({ }^{\circ} \mathrm{C}\right)$ & $(\mathbf{m})$ \\
\hline Low & $0.5 \pm 0.3$ & $0.5 \pm 0.3$ & $69 \pm 15.8$ & $7 \pm 0.5$ & $85 \pm 8.6$ & $7 \pm 0.2$ & $21.6 \pm 3.4$ & $3 \pm 1.4$ \\
\hline Medium & $0.6 \pm 0.3$ & $0.4 \pm 0.2$ & $131 \pm 95$ & $5.1 \pm 1.0$ & $59.1 \pm 11.5$ & $7 \pm 0.5$ & $21 \pm 1.1$ & $2 \pm 1.2$ \\
\hline High & $0.4 \pm 0.2$ & $0.2 \pm 0.2$ & $279 \pm 134.1$ & $5.3 \pm 0.9$ & $66.6 \pm 13.8$ & $7 \pm 0.4$ & $24 \pm 1.6$ & $3 \pm 1.3$ \\
\hline
\end{tabular}

Descriptors include Depth $(\mathrm{m})=$ stream depth; Veloc. $(\mathrm{m} / \mathrm{s})=$ water velocity; Cond. $\left(\mu \mathrm{S} / \mathrm{cm}^{-1}\right)=$ conductivity; Oxig. $(\mathrm{mg} / \mathrm{l})=$ dissolved oxygen; Oxig. $(\%)=$ oxygen saturation; $\mathrm{pH}$; Temp. $\left({ }^{\circ} \mathrm{C}\right)=$ water temperature; Width $(\mathrm{m})=$ stream width.

Table 2. Analysis of percentage of land use and cover sampled among the different urbanization levels on streams, i.e., low (Curral de Arame microbasin), medium (Laranja Doce microbasin), and high (Água Boa microbasin), in the Ivinhema River Basin, Upper Paraná River Basin.

\begin{tabular}{cccc}
\hline & Curral de Arame & Laranja Doce & Água Boa \\
\hline Forest fragments & $29.7 \%$ & $18.2 \%$ & $15.5 \%$ \\
Agriculture & $60.6 \%$ & $62.8 \%$ & $49.3 \%$ \\
Water bodies & $4.2 \%$ & $4.8 \%$ & $6.0 \%$ \\
Urban buildings & $5.5 \%$ & $14.2 \%$ & $29.2 \%$ \\
\hline
\end{tabular}


sampled to obtain a comparable species richness estimator by site and posteriorly this rarefied richness values were compared using Analysis of Variance (ANOVA) with a posteriori Tukey test.

The difference in fish assemblage similarity considering the different urbanization levels, was tested by a Permutational Multivariate Analysis of Variance (PERMANOVA main test), applied on a Bray-Curtis similarity matrix generated from species abundance data, and significance in estimated differences were estimated by Monte Carlo permutations (999 permutations). We applied a posteriori tests (pairwise tests) if the different urbanization levels or their interaction were statistically significant. To summarize graphically differences in species composition, we conducted a Principal Coordinates Analysis (PCoA) using the Bray-Curtis distance matrix and samples points were grouped among the different urbanization levels. For the interpretation of PCoA, the scores of the first two axes were presented graphically.

The indicator value (IndVal) of Dufrêne and Legendre (1997) was used to identify if and what species can be used as indicators of antropic level groups (De Cáceres et al., 2010). This value was obtained for each species from the original untransformed data matrix, using a 'multipatt' routine in the indicspecies package (Caceres and Jansen, 2010). The values with type I error probabilities $<5 \%(\mathrm{p}<0.05$; result of a Monte Carlo test based on 999 permutations) served to identify the potential indicator species.

To evaluate environmental influence on rarefied richness in areas with different urbanization levels, we used a recursive partitioning technique called conditional inference tree analysis. A conditional inference tree (CIT) is a non-parametric technique that splits a dataset into binary groups repeatedly based on the association between the predictor variables (environmental variables) and the response variable (rarefied richness) in order to generate a decision/regression tree (Hothorn et al., 2006b).

Species were classified by their relative abundances, according to the urbanization level, to determine species distributions along the urbanization gradient. The analyses were performed in the R Statistical Program (R Development Core Team, 2021).

\section{Results}

A total of 4,320 specimens were collected, including 937 individuals in low (Curral de Arame - CA), 1,071 in medium (Laranja Doce - LD), and 2,312 in high (Água Boa - AB) urbanization levels. In total, we sampled 57 species distributed among 6 orders and 17 families. A total of 31 species were sampled in areas with low, 46 species in areas with medium, and 23 species in areas with high urbanization levels. Bootstrap estimated the richness of species sampled at microbasin scale as $34 \pm 2.1$ for low, $53 \pm 3.98$ for medium, and $27 \pm 2.6$ for high urbanization levels, matching the pattern observed for species richness. Therefore, approximately $92 \%$ of total species was sampled in areas with low, $87 \%$ with medium, and $85 \%$ with high urbanization level.

Characiformes, Siluriformes, Characidae and Loricariidae were the most abundant orders and families at all urbanization levels (Figure 2). The most abundant species sampled in areas with low urbanization level were Piabarchus stramineus (17.5\%), followed by Serrapinnus notomelas (14.4\%) and Astyanax lacustris (13.3\%); at the medium level, they were Corydoras aeneus (16.9\%), followed by Hypostomus ancistroides (14.9\%) and Serrapinnus notomelas (14.4\%), and at high level, they were Serrapinnus notomelas (45.4\%), Poecilia reticulata (28.7\%), and Corydoras aeneus (6.5\%).

Irrespective of the number of sampling sites, the species accumulation curve (Figure 3 ) showed that sites with a medium urbanization level had higher cumulative richness (46 species), while areas with high urbanization level showed lower cumulative richness (23 species). Low (31 species) and high urbanization levels showed a tendency towards stabilization of species richness independent of increase in the number of samples sites.

A significant difference in rarefied richness was observed among areas with different urbanization levels $\left(\mathrm{F}_{2.28}=15.64 ; \mathrm{p}<0.001\right)$ (Figure 4$)$. The higher rarefied richness values were observed at low and medium urbanization levels, while the lower mean rarefied richness was found at high urbanization levels. The differences were significant between low and high urbanization levels and between medium and high levels.
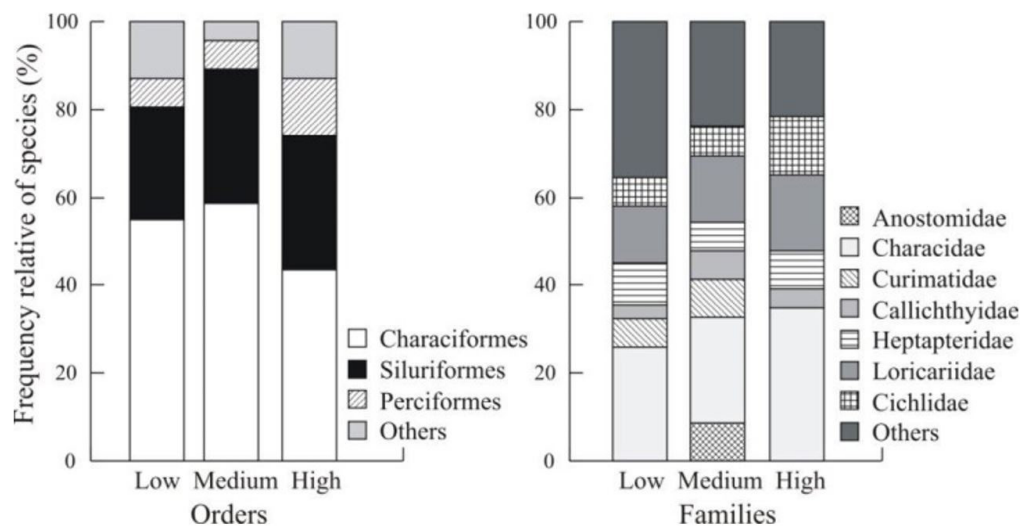

Figure 2. Relative frequency of species by order and family sampled among the different urbanization levels (low, medium, and high) in the Ivinhema River Basin, Upper Paraná River Basin. 


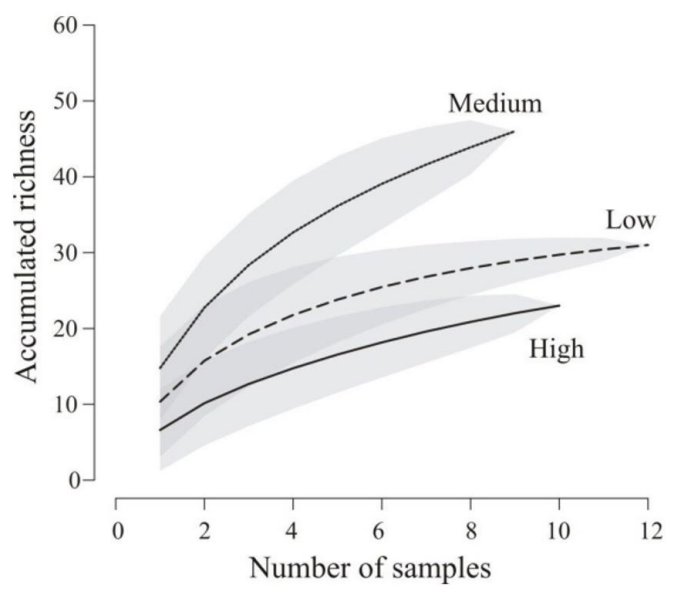

Figure 3. Species accumulation curves based on the number of samples among the different urbanization levels (low, medium, and high) in the Ivinhema River Basin, Upper Paraná River Basin.

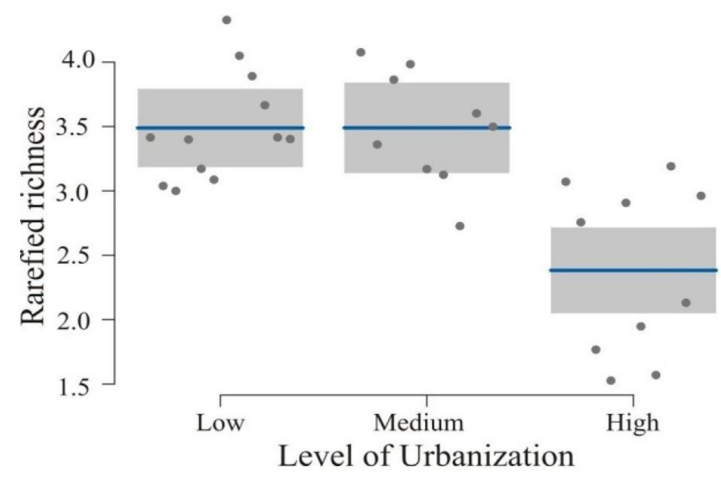

Figure 4. Variation in rarefied species richness among the different urbanization levels (low, medium, and high) in the Ivinhema River Basin, Upper Paraná River Basin.

Significant differences were found in species composition among low, medium and high urbanization levels ( $\mathrm{F}=5.41$; $\mathrm{p}=0.001)$. Three species showed significant IndVal values ( $\mathrm{p}<0.05$ ) at the low level, six species at the medium level, and two species at high urbanization levels (Figure 5), reinforcing differences in species distributions along the urbanization gradient.

CIT results (Figure 6) showed that conductivity ( $\mathrm{p}=0.026$ ) was a better predictor variable for rarefied species richness. The higher mean values for rarefied richness were observed in sites with conductivity values $<191.1 \mu \mathrm{S} / \mathrm{cm}^{-1}$, and the lower mean rarefied richness values were observed in areas with conductivity $>191.1 \mu \mathrm{S} / \mathrm{cm}^{-1}$.

Through the ordination of fish species using relative abundance by urbanization level, four species groups were identified: I - species occurring in areas with low urbanization level; II - species occurring at all urbanization levels; III - species occurring in areas with medium urbanization level; and IV - species occurring in areas with high urbanization level (Figure 7).

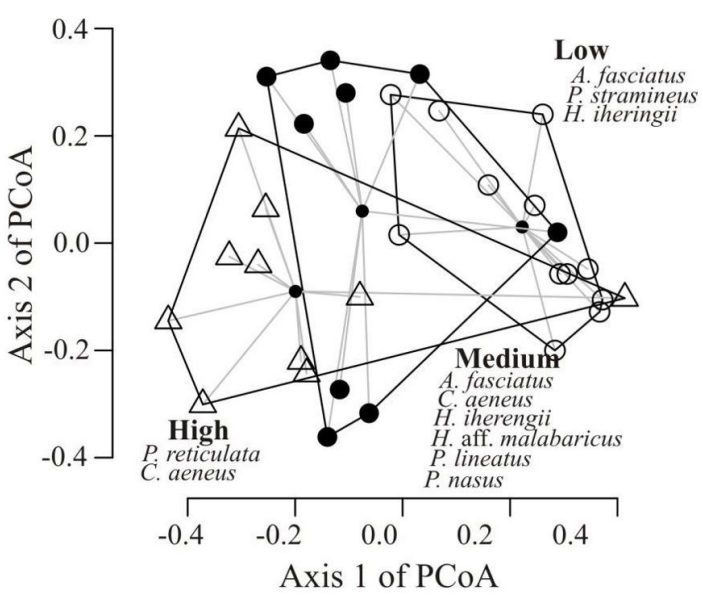

Figure 5. Principal Coordinates Analysis (PCoA) of species abundances sampled among streams the different urbanization levels (low, medium, and high) in the Ivinhema River Basin, Upper Paraná River Basin. Add species indicators of each level (Indval).

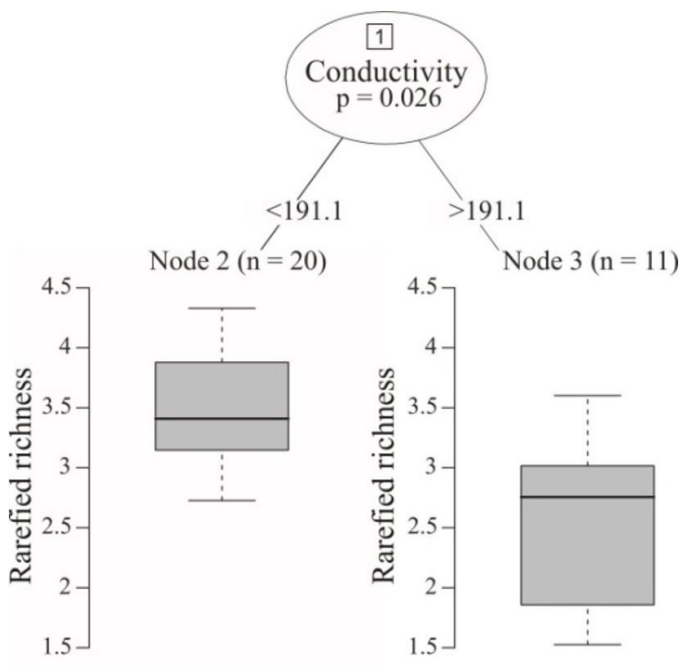

Figure 6. Conditional inference tree (CIT) of environmental variables by richness among the different urbanization levels (low, medium, and high) in the Ivinhema River Basin, Upper Paraná River Basin.

Group I consisted of thirteen species with relative abundance distributed in the low and medium levels, occurring predominantly in areas with low urbanization. We highlight the occurrence of Melanorivulus apiamici, which was found only in this group. Group II consisted of fourteen species distributed among all urbanization levels, occurring predominantly in areas with low and medium urbanization, highlighting the occurrence of Astyanax lacustris in 28 of the 31 sample sites. Group III included eighteen species occurring exclusively in areas of medium urbanization. In these areas, we highlight a strong predominance of medium and large species, such as Salminus hilarii. Group IV was formed by twelve species distributed in areas with low, medium and high urbanization, but occurring predominantly in areas of 


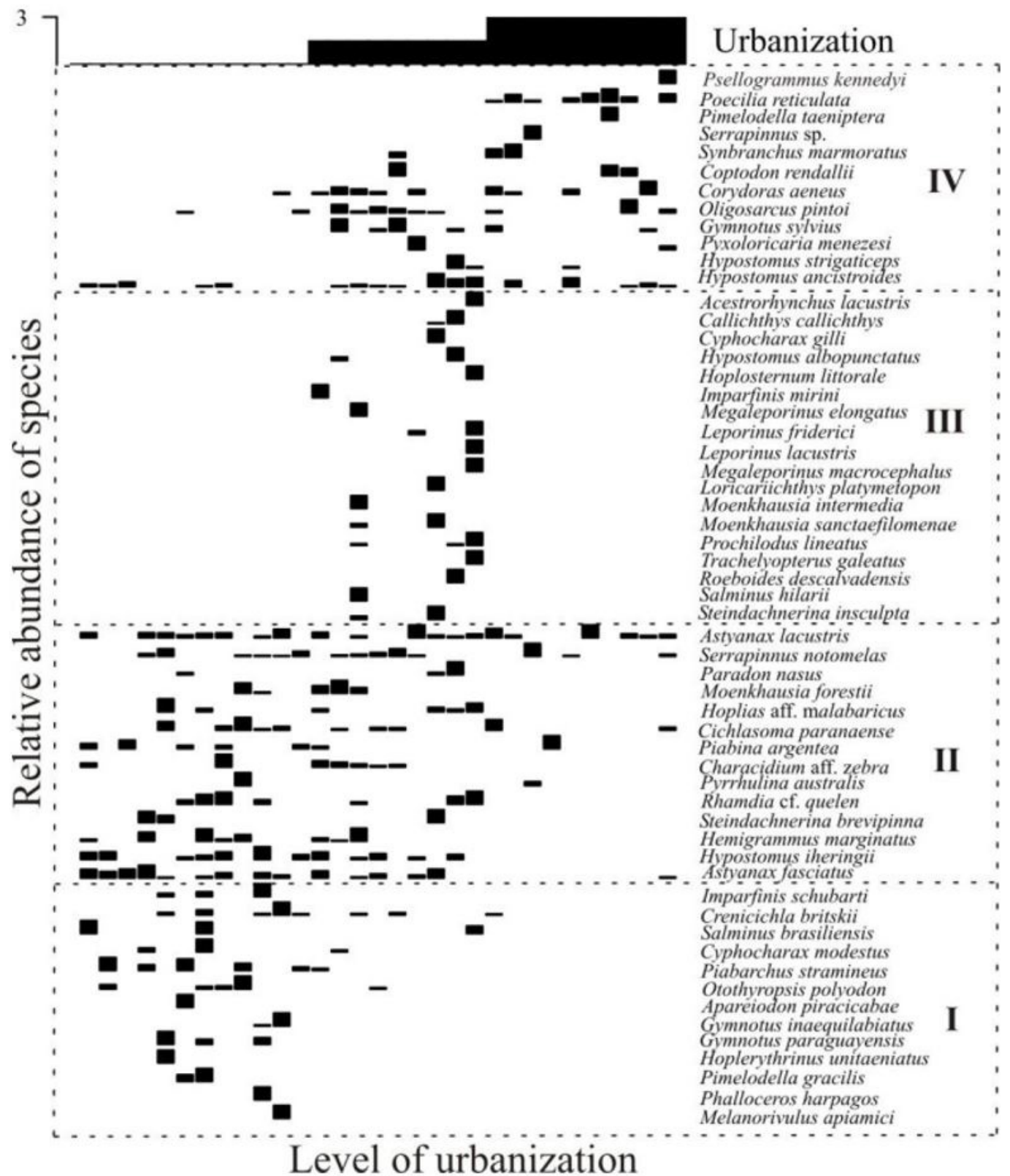

Figure 7. Fish species relative abundances across areas with different urbanization levels (low, medium and high) in the Ivinhema River Basin, Upper Paraná River Basin. I - low urbanization level; II - (species occurring in) all urbanization levels; III - medium urbanization level; and IV - high urbanization level.

medium and high urbanization. Poecilia reticulata occurred exclusively in this group.

\section{Discussion}

Studies reporting changes in fish communities in rivers and streams have emphasized that environmental modification, including changes occurring through the effects of urbanization, can directly influence species composition and diversity (Felipe and Súarez, 2010; Casatti et al., 2012), as well as reproductive biology (Limburg and Schmidt, 1990).

The predominance of Characiformes and Siluriformes is expected from studies in the Neotropical region since Characidae and Loricariidae families are predominantly found in the Ivinhema River Basin (Felipe and Súarez 2010; Súarez et al., 2011) in the Upper Paraná River Basin (LoweMcConnell, 1999; Oyakawa and Menezes, 2011). The most abundant species by urbanization level were Piabarchus 
stramineus (low), Corydoras aeneus (medium) and Poecilia reticulata (high). The abundance of these species may be associated with displacement capacity of each species combined with predominant local characteristics (Castro, 1999; Winemiller and Willis, 2011), including limnological variables associated with the urbanization level that may limit the occurrence and abundance of other species (Cunico et al., 2006).

Piabarchus stramineus showed higher abundance values in streams with low urbanization, namely the Curral de Arame microbasin. These streams presented higher water velocity and oxygen concentration, but lower electrical conductivity, compared to other streams with low and high levels of urbanization. High abundance values for $P$. stramineus in streams with higher water velocity and lower electrical conductivity values have been previously reported by Súarez (2008). The occurrence of this species in these areas is highly likely owing to morphological adaptations to specific hydrological features, which, in turn, significantly influence its distribution (Súarez et al., 2007). Furthermore, P. stramineus is predominantly insectivorous (Casatti et al., 2003), feeding on insects carried by the river current (Grant and Noakes, 1987), terrestrial insects captured on the surface (Sazima, 1986), and various autochthonous items (Brandão-Gonçalves et al., 2009). Both allochthonous and autochthonous food items consumed by P. stramineus, are extremely dependent on riparian vegetation (Alvim and Peret, 2004). Areas with strong currents have increased oxygen content and resource availability generally associated with riparian vegetation. This suggests that $P$. stramineus may require less impacted habitat in favor of a narrower range of environmental conditions (Lorion and Kennedy, 2009). Casatti et al. (2006) also found that the occurrence of $P$. stramineus indicated high integrity of habitats in the São José dos Dourados Basin (Paraná River), corroborating our results.

Corydoras aeneus was the most abundant species in streams with medium urbanization (Laranja Doce microbasin). The abundance of this species may be related to the lack of riparian vegetation, a condition which promotes growth of grasses, thereby contributing to an increase in structural complexity (Collier et al., 1999). However, the high incidence of marginal grasses may also have negative effects on aquatic organisms, making these habitats less favorable for juveniles of large species and affecting predator-prey interactions (Casatti et al., 2009). Moreover, the high abundance of $C$. aeneus is indicative of changes in water quality (Vieira and Shibatta, 2007). Casatti et al. (2009) found a higher relative abundance of $C$. aeneus in streams with grass compared to streams without grass, in addition to higher $C$. aeneus abundance in areas lacking riparian vegetation. Teresa and Casatti (2010) found similar results, corroborating our findings and highlighting the importance of riparian vegetation for fish communities.

In streams affected by a high level of urbanization, namely Água Boa microbasin, P. reticulata was the most abundant species. Poeciliid species were first introduced in several Brazilian basins as a biological control agent of insect larvae (Graça and Pavanelli, 2007). However, high abundances in natural environments may indicate environmental degradation (Caetano et al., 2016). Based on its high capacity to colonize different environments from freshwater to saltwater, it is more successful in lentic environments (Britski et al., 2007). Furthermore, $P$. reticulata is considered resistant to the effects of environmental degradation by its opportunistic feeding behavior, utilizing different types of debris (Oliveira and Bennemann, 2005). Compared to more specialized species, this confers the advantage of avoiding high temperatures in large and shallow streams and becoming more abundant in disturbed habitats (Vieira and Shibatta, 2007).

The species accumulation curve and rarefaction analysis showed higher species richness at medium urbanization level when compared with other urbanization levels. In part, this could be explained by the intermediate disturbance hypothesis proposed by Connell (1978), who suggested that habitats with intermediate levels of disturbance reduce the competitive ability of dominant species, thereby producing higher resource availability for others and reducing competitive exclusion of rare species, the end result of which is higher species diversity (Leidy and Fiedler, 1985). However, high disturbance levels reduce the numbers of specialist and generalist species, resulting in reduced diversity (Casatti et al., 2010), corroborating our results which found low species richness in streams with a high level of urbanization. In this sense, disturbance can create new conditions that may benefit more tolerant species (Teresa and Casatti, 2012). This pattern has been reported in several studies with fish in highly impacted environments (Felipe and Súarez, 2010)

The difference in species composition and relative abundance among different urbanization levels demonstrates that urbanization acts as a filter to reduce colonization and persistence of some species in sites with variation in environmental conditions, while facilitating colonization by more tolerant species (Peressin and Cetra, 2014). In addition, IndVal results showed the occurrence of indicator species of environmental integrity, suggesting more heterogeneous environmental conditions. Heterogeneity is positively associated with habitat complexity (Ibanez et al., 2007), which promotes an increase in species richness. On the other hand, locations with lower water velocity and depth, i.e., shallower and lentic sites, showed lower rarefied richness, suggesting a more homogeneous habitat. More homogeneous sites tend to present less complexity, which can generate restrictive conditions that permit only a few species to thrive, thus decreasing species richness. Therefore, habitat homogenization can directly affect fish populations (Torgersen and Close, 2004) and communities (Schneider and Winemiller, 2008). Casatti et al. (2009) analyzed the effects of habitat homogenization and found that heterogeneous sites had greater species richness, while homogeneous sites had lower species richness and high dominance of exotic species, suggesting changes in water quality and habitat degradation (Alexandre et al., 2010).

At sites with low and medium urbanization, indicator species demonstrate that environmental conditions may permit the occurrence of medium and large species, which are mainly associated with greater water depth. However, low oxygen concentration in 'intermediate' areas can also benefit tolerant species with the ability to colonize and persist in hypoxic sites. In conditions of high urbanization, 
the indicator species show decreased environmental integrity, favoring the occurrence of more tolerant species (McDonald et al., 2020). Thus, the distribution and abundance of species over the urbanization gradient are directly linked to the ability of species to tolerate physical and biological conditions in the environment (Whittaker, 1967; McDonnell et al., 1993).

It was reported that sampling sites with low urbanization show the highest integrity values, in which the environment generally have low numbers of dominant species and absence of exotic species, while rivers and streams have a high contribution of allochthonous input, such as seeds, fruits, and insects (Lorion and Kennedy, 2009; Casatti et al., 2012). At medium level of urbanization, species richness is higher, but it is also possible that native specialists will be replaced by exotic species more tolerant to high temperatures (Casatti et al., 2009, 2012). For example, $C$. aeneus has high abundance in areas with high urbanization level, which are also areas that commonly have little, to no, vegetative cover. Lack of vegetation can facilitate soil erosion (Klein, 1979), resulting in stream channel modifications (Weaver and Garman, 1994) that make the water body wider and shallower. This can alter the input of allochthonous material (Cunico et al., 2012) and physicochemical parameters, increase temperature, and decrease oxygen concentration. These changes often lead to a reduction in structural complexity (Stefani and Smith, 2014) and environmental heterogeneity, favoring the dominance of opportunistic species (Rocha et al., 2009), e.g., P. reticulata, which was sampled only at high urbanization level in the current study.

Our ordering of relative abundance corroborated previous results showing a trend toward reduction in species richness with higher urbanization levels (Dias and Tejerina-Garro, 2010; Peressin and Cetra, 2014). The ordering of species by environmental gradient has been used in other studies (Whittaker, 1967), and it is considered a consistent method for ecological studies of the effects of urbanization (Ter Braak and Prentice, 1988). The degree of environmental change in an area determines structure and ecosystem function (McDonnell and Pickett, 1990), as well as the distribution and behavior of ecological systems along the gradient (Roberts, 1987).

According to Gray (1989), increased disturbance causes reduction in habitat features, and partial reduction of environmental integrity may result in increased species richness and increased representation of species able to withstand environmental change (Bojsen and Barriga, 2002). As a consequence, population sizes reduce (Takahashi et al., 2013), and local species with more specialized habits may either be reduced or driven to local extinction (Smith, 2003).

In summary, urbanization directly influences the richness, composition, and structure of stream fish assemblages. These assemblages are exposed to various negative impacts as a result of urbanization. Changes in biotic and abiotic factors can reduce species richness and make environments highly susceptible to species losses with consequent reduction in diversity. This situation could favor species capable of colonizing and persisting in these sites, for example, $P$. reticulata, which occurred only in areas with a high level of urbanization. Although our study did not address conservation or management practices in urban streams, our results have strong implications for the establishment of such policies for conservation of fish assemblies in the Ivinhema River Basin.

\section{Acknowledgements}

The authors thank Lidiani Q. L. Ximenes and Olemar C. Martins for sharing data; Gabriela S. V. Duarte, Maiane J. Pereira, Olemar C. Martins, Marcelo M. Souza and Madson S. Melo for logistical support in the field and laboratory. We are grateful to Wagner Vicentin for the assistance with analyses and helpful suggestions. The Instituto de Meio Ambiente de Dourados (IMAM), CNPq, FUNDECT, UEMS, and FAPEMS provided logistical and financial support, and the Coordenação de Aperfeiçoamento de Pessoal de Nível Superior (Capes) provided a Master's student fellowship to the first author.

\section{References}

ALEXANDRE, C.V., ESTEVES, K.E. and DE MOURA E MELLO, M.A.M., 2010. Analysis of fish communities along a rural-urban gradient in a neotropical stream (Piracicaba River Basin, São Paulo, Brazil). Hydrobiologia, vol. 641, no. 1, pp. 97-114. http://dx.doi. org/10.1007/s10750-009-0060-y.

ALVIM, M.C.C. and PERET, A.C., 2004. Food resources sustaining the fish fauna in a section of the upper São Francisco River in Três Marias, MG, Brazil. Brazilian Journal of Biology = Revista Brasileira de Biologia, vol. 64, no. 2, pp. 195-202. https://doi. org/10.1590/S1519-69842004000200003.

BOJSEN, B.H. and BARRIGA, R., 2002. Effects of deforestation on fish community structure in Ecuadorian Amazon streams. Freshwater Biological Laboratory, vol. 47, no. 11, pp. 2246-2260. http://dx.doi.org/10.1046/j.1365-2427.2002.00956.x.

BRANDÃO-GONÇALVES, L., LIMA-JUNIOR, S.E. and SUAREZ, Y.R., 2009. Hábitos alimentares de Bryconamericus stramineus Eigenmann, 1908 (Characidae), em diferentes riachos da sub-bacia do Rio Guiraí, Mato Grosso do Sul, Brasil. Biota Neotropica, vol. 9, no. 1, pp. 135-143. http://dx.doi.org/10.1590/ S1676-06032009000100016.

BRITSKI, H.A., SILIMON, K.Z. and LOPES, B.S., 2007. Peixes do Pantanal: manual de identificação. Brasília: Embrapa.

CACERES, M.D. and JANSEN, F., 2010 [viewed 8 January 2021]. Indicspecies: functions to assess the strength and significance of relationship of species site group associations. Version 1.5.1 [online]. Vienna: R Core Team. Available from: http://cran.rproject.org/web/packages/indicspecies/index.html

CAETANO, D.L.F., OLIVEIRA, E.F. and ZAWADZKI, C.H., 2016. Fish species indicators of environmental variables of Neotropical streams in southern Brazil, upper Paraná River basin. Acta Ichthyologica et Piscatoria, vol. 46, no. 2, pp. 87-96. http:// dx.doi.org/10.3750/AIP2016.46.2.04.

CASATTI, L., DE PAULA FERREIRA, C. and CARVALHO, F.R., 2009. Grass-dominated stream sites exhibit low fish species diversity and dominance by guppies: an assessment of two tropical pasture river basins. Hydrobiologia, vol. 632, no. 1, pp. 273-283. http://dx.doi.org/10.1007/s10750-009-9849-y.

CASATTI, L., LANGEANI, F., SILVA, A.M. and CASTRO, R.M.C., 2006. Stream fish, water and habitat quality in a pasture dominated basin, Southeastern Brazil. Brazilian Journal of Biology = Revista 
Brasileira de Biologia, vol. 66, no. 2B, pp. 681-696. http://dx.doi. org/10.1590/S1519-69842006000400012. PMid:16906300.

CASATTI, L., MENDES, H.F. and FERREIRA, K.M., 2003. Aquatic macrophytes as feeding site for small fishes in the Rosana reservoir, Paranapanema river, southeastern Brazil. Brazilian Journal of Biology = Revista Brasileira de Biologia, vol. 63, no. 2, pp. 213-222. http://dx.doi.org/10.1590/S1519-69842003000200006. PMid:14509843.

CASATTI, L., ROMERO, R.M., TERESA, F.B., SABINO, J. and LANGEANI, F., 2010. Fish community structure along a conservation gradient in Bodoquena Plateau streams, central West of Brazil. Acta Limnologica Brasiliensia, vol. 22, no. 1, pp. 50-59. http://dx.doi. org/10.4322/actalb.02201007.

CASATTI, L., TERESA, F.B., GONÇALVES-SOUZA, T., BESSA, E., MANZOTTI, A.R., GONÇALVES, C.S. and ZENI, J.O., 2012. From forests to cattail: how does the riparian zone influence stream fish? Neotropical Ichthyology, vol. 10, no. 1, pp. 205-214. http:// dx.doi.org/10.1590/S1679-62252012000100020.

CASTRO, R.M.C., 1999. Evolução da ictiofauna de riachos sulamericanos: padrões gerais e possíveis processos causais. In: E.P. CARAMASCHI, R. MAZZONI and P.R. PERES-NETO, eds. Ecologia de peixes de riachos. Rio de Janeiro: UFRJ, vol. 6, no. 1, pp. 139-155. Série Oecologia Brasiliensis. http://dx.doi. org/10.4257/oeco.1999.0601.04.

CHAUDHARY, A., POURFARAJ, V. and MOOERS, A.O., 2018. Projecting global land use-driven evolutionary history loss. Diversity E' Distributions, vol. 24, no. 2, pp. 158-167. http://dx.doi. org/10.1111/ddi.12677.

COLLIER, K.J., CHAMPION, P.D. and CROKER, G.F., 1999. Patchand reach-scale dynamics of a macrophyte-invertebrate system in a New Zealand lowland stream. Hydrobiologia, vol. 392, no. 2, pp. 89-97. http://dx.doi.org/10.1023/A:1003653717805.

CONNELL, J.H., 1978. Diversity in tropical rain forest and coral reefs. Science, vol. 199, no. 4335, pp. 1302-1310. http://dx.doi. org/10.1126/science.199.4335.1302. PMid:17840770.

CUNICO, A.M., AGOSTINHO, A.A. and LATINI, J.D., 2006. Influência da urbanização sobre as assembleias de peixes em três córregos de Maringá, Paraná. Revista Brasileira de Zoologia, vol. 23, no. 4, pp. 1101-1110. http://dx.doi.org/10.1590/S010181752006000400018 .

CUNICO, A.M., FERREIRA, E.A., AGOSTINHO, A.A., BEAUMORD, A.C. and FERNANDES, R., 2012. The effects of local and regional environmental factors on the structure of fish assemblages in the Pirapó Basin, Southern Brazil. Landscape and Urban Planning, vol. 105, no. 3, pp. 336-344. http://dx.doi.org/10.1016/j. landurbplan.2012.01.002.

DAGA, V.S., GUBIANI, E.A., CUNICO, A.M. and BAUMGARTNER, G. 2012. Effects of abiotic variables on the distribution of fish assemblages in streams with different anthropogenic activities in southern Brazil. Neotropical Ichthyology, vol. 10, no. 3, pp. 643-652. http://dx.doi.org/10.1590/S1679-62252012000300018.

DE CÁCERES, M., LEGENDRE, P. and MORETTI, M., 2010. Improving indicator species analysis by combining groups of sites. Oikos, vol. 119, no. 10, pp. 1674-1684. https://doi.org/10.1111/j.16000706.2010.18334.x.

DIAS, A.M. and TEJERINA-GARRO, F.L., 2010. Changes in the structure of fish assemblages in streams along an undisturbed-impacted gradient, upper Paraná River basin, Central Brazil. Neotropical Ichthyology, vol. 8, no. 3, pp. 587-598. http://dx.doi.org/10.1590/ S1679-62252010000300003.

DUFRÊNE, M. and LEGENDRE, P., 1997. Species assemblages and indicator species: the need for a flexible asymmetrical approach. Ecological Monographs, vol. 67, no. 3, pp. 345-366. http://dx.doi. org/10.2307/2963459.

ENVIRONMENTAL SYSTEMS RESEARCH INSTITUTE - ESRI, 2015. ArcGIS Desktop: Release 10.4. Redlands, CA: ESRI.
FELIPE, T.R.A. and SÚAREZ, Y.R., 2010. Characterization and influence of environmental factors on stream fish assemblages in two small urban sub-basins, Upper Paraná River. Biota Neotropica, vol. 10, no. 2. http://dx.doi.org/10.1590/S1676-06032010000200018.

GRAÇA, W.J. and PAVANELLI, C.S., 2007. Peixes da planície de inundação do alto rio Paraná e áreas adjacentes. Maringá: EDUEM.

GRANT, J.W.A. and NOAKES, D.L.G., 1987. A simple model of optimal territory size for drift feeding fishes. Canadian Journal of Zoology, vol. 65, no. 2, pp. 270-276. http://dx.doi.org/10.1139/z87-042.

GRAY, J.S., 1989. Effects of environmental stress on species rich assemblages. Biological Journal of the Linnean Society. Linnean Society of London, vol. 37, no. 1-2, pp. 19-32. http://dx.doi. org/10.1111/j.1095-8312.1989.tb02003.x.

HELLMANN,J.J. and FOWLER, G.W., 1999. Bias, precision and accuracy of four measures of species richness. Ecological Applications, vol. 9, no. 3, pp. 824-834. https://doi.org/10.2307/2641332.

HOEINGHAUS, D.J., WINEMILLER, K.O. and BIRNBAUM, J.S., 2006. Local and regional determinants of stream fish assemblage structure: inferences based on taxonomic vs. functional groups. Journal of Biogeography, vol. 34, no. 2, pp. 324-338. http://dx.doi. org/10.1111/j.1365-2699.2006.01587.x.

HONNEN, W., RATH, K., SCHLEGEL, T., SCHWINGER, A. and FRAHNE, D., 2001. Chemical analyses of water, sediment and biota in two small streams in southwest Germany. Journal of Aquatic Ecosystem Stress and Recovery, vol. 8, no. 3-4, pp. 195-213. http://dx.doi.org/10.1023/A:1012945427446.

HOTHORN, T., HORNIK, K. and ZEILEIS, A., 2006b. Unbiased recursive partitioning: a conditional inference framework. Journal of Computational and Graphical Statistics, vol. 15, no. 3, pp. 651-674. http://dx.doi.org/10.1198/106186006X133933.

IBANEZ, C., OBERDORFF, T., TEUGELS, G., MAMONONEKENE, V., LAVOUÉ, S., FERMON, Y., PAUGY, D. and TOHAM, A.K., 2007. Fish assemblages structure and function along environmental gradients in rivers of Gabon (Africa). Ecology Freshwater Fish, vol. 16, no. 3, pp. 315-334. http://dx.doi.org/10.1111/j.16000633.2006.00222.x.

JACKSON, D.A., PERES-NETO, P.R. and OLDEN, J.D., 2001. What controls who is where in freshwater fish assemblages: the roles of biotic, abiotic, and spatial factors. Canadian Journal of Fisheries and Aquatic Sciences, vol. 58, no. 1, pp. 157-170.

JOHNSON, R.K., GOEDKOOP, W. and SANDIN, L., 2004. Spatial scale and ecological relationships between the macroinvertebrate communities of stony habitats of streams and lakes. Freshwater Biology, vol. 49, no. 9, pp. 1179-1194. http://dx.doi.org/10.1111/ j.1365-2427.2004.01262.x.

KLEIN, R.D., 1979. Urbanization and stream quality impairment. Journal of the American Water Resources Association, vol. 15, no. 4, pp. 948-963. http://dx.doi.org/10.1111/j.1752-1688.1979. tb01074.x.

LEIDY, R.A. and FIEDLER, P.L., 1985. Human disturbance and patterns of fish species diversity in the San Francisco Bay drainage, California. Biological Conservation, vol. 33, no. 3, pp. 247-267. http://dx.doi.org/10.1016/0006-3207(85)90016-3.

LIMBURG, K.E. and SCHMIDT, R.E., 1990. Patterns of fish spawning in Hudson River Tributaries: response to an urban gradient? Ecological Society of America, vol. 71, no. 4, pp. 1238-1245. http://dx.doi.org/10.2307/1938260.

LORION, C.M. and KENNEDY, B.P., 2009. Riparian forest buffers mitigate the effects of deforestation on fish assemblages in tropical headwater streams. Ecological Applications, vol. 19, no. 2, pp. 468-479. http://dx.doi.org/10.1890/08-0050.1. PMid: 19323203.

LOWE-MCCONNELL, R.H., 1999. Estudos ecológicos de comunidades de peixes tropicais. São Paulo: EDUSP, 534 p. Coleção base.

MCDONALD, R.I., MANSUR, A.V., ASCENSÃO, F., COLBERT, M.L., CROSSMAN, K., ELMQVIST, T., GONZALEZ, A., GÜNERALP, B., 
HAASE, D., HAMANN, M., HILLEL, O., HUANG, K., KAHNT, B., MADDOX, D., PACHECO, A., PEREIRA, H.M., SETO, K.C., SIMKIN, R., WALSH, B., WERNER, A.S. and ZITER, C., 2020. Research gaps in knowledge of the impact of urban growth on biodiversity. Nature Sustainability, vol. 3, no. 1, pp. 16-24. http://dx.doi. org/10.1038/s41893-019-0436-6.

MCDONNELL, M.J. and PICKETT, S.T.A., 1990. The study of ecosystem structure and function along urban-rural gradients: an unexploited opportunity for ecology. Ecology, vol. 71, no. 4, pp. 1232-1237. http://dx.doi.org/10.2307/1938259.

MCDONNELL, M.J., PICKETT, S.T.A. and POUYAT, R.V., 1993. The application of the ecological gradient paradigm to the study of urban effects. In: M.J. MCDONNELL and S.T.A. PICKETT, eds. Humans as components of ecosystems. New York: Springer-Verlag, pp. 175-189. http://dx.doi.org/10.1007/978-1-4612-0905-8_15.

MCKINNEY, M.L., 2006. Urbanization as a major cause of biotic homogenization. Biological Conservation, vol. 127, no. 3, pp. 247-260. http://dx.doi.org/10.1016/j.biocon.2005.09.005.

MOUILLOT, D., GRAHAM, N.A.J., VILLÉGER, V., MASON, N.W.H. and BELLWOOD, D.R., 2012. A functional approach reveals community responses to disturbances. Trends in Ecology $\mathcal{E}$ Evolution, vol. 28, no. 3, pp. 167-177. http://dx.doi.org/10.1016/j. tree.2012.10.004. PMid:23141923.

OLDEN, J.D. and POFF, N.L., 2003. Toward a mechanistic understanding of prediction of biotic homogenization. The American Naturalis, vol. 162, no. 4, pp. 442-460. http://dx.doi. org/10.1086/378212. PMid:14582007.

OLIVEIRA, D.C. and BENNEMANN, S.T., 2005. Ictiofauna, recursos alimentares e relações com as interferências antrópicas em um riacho urbano no sul do Brasil. Biota Neotropica, vol. 5, no. 1, pp. 95-107. http://dx.doi.org/10.1590/S1676-06032005000100011.

OYAKAWA, O.T. and MENEZES, N.A., 2011. Checklist dos peixes de água doce do Estado de São Paulo, Brasil. Biota Neotropica, vol. 11, suppl. 1, pp. 19-32. http://dx.doi.org/10.1590/S167606032011000500002.

PAUL, M.J. and MEYER, J.L., 2001. Streams in the urban landscape. Annual Review of Ecology and Systematics, vol. 32, no. 1, pp. 333-365. http://dx.doi.org/10.1146/annurev. ecolsys.32.081501.114040.

PERESSIN, A. and CETRA, M., 2014. Responses of the ichthyofauna to urbanization in two urban areas in Southeast Brazil. Urban Ecosystems, vol. 17, no. 3, pp. 675-690. http://dx.doi.org/10.1007/ s11252-014-0352-5.

R DEVELOPMENT CORE TEAM, 2021. [software]. [viewed 8 January 2021]. Available from: http://www.R-project.org.

ROBERTS, D.W., 1987. A dynamical systems perspective on vegetation theory. Vegetatio, vol. 69, no. 1-3, pp. 27-33. http://dx.doi. org/10.1007/BF00038684.

ROCHA, F.C., CASATTI, L., CARVALHO, F.R. and SILVA, A.M., 2009. Fish assemblages in stream stretches occupied by cattail (Typhaceae, Angiospermae) stands in Southeast Brazil. Neotropical Ichthyology, vol. 7, no. 2, pp. 241-250. http://dx.doi. org/10.1590/S1679-62252009000200016.

SAZIMA, I., 1986. Similarities in feeding behavior between some marine and freshwater fishes in two tropical communities. Journal of Fish Biology, vol. 29, no. 1, pp. 53-65. http://dx.doi. org/10.1111/j.1095-8649.1986.tb04926.x.

SCHLOSSER, I.J., 1982. Fish community structure and function along two habitat gradients in a headwater stream. Ecological Monographs, vol. 52, no. 4, pp. 395-414. http://dx.doi. org/10.2307/2937352.

SCHNEIDER, K.N. and WINEMILLER, K.O., 2008. Structural complexity of woody debris patches influences fish and macroinvertebrate species richness in a temperate floodplain-river system. Hydrobiologia, vol. 610, no. 1, pp. 235-244. http://dx.doi. org/10.1007/s10750-008-9438-5.
SMITH, E.P. and VAN BELLE, G., 1984. Non-parametric estimation of species richness. Biometrics, vol. 40, no. 1, pp. 119-129. http:// dx.doi.org/10.2307/2530750.

SMITH, W.S., 2003. Os Peixes do Rio Sorocaba: A história de uma bacia hidrográfica. Sorocaba: Editora TCM Comunicação.

STEFANI, M.S. and SMITH, W.S., 2014. A ictiofauna do rio Tatuí, SP, Brasil sob influência de impactos ambientais. Brazilian Journal of Aquatic Science and Technology, vol. 18, no. 2, pp. 43-52. http:// dx.doi.org/10.14210/bjast.v18n2.p43-52.

SÚAREZ, Y.R., 2008. Variação espacial e temporal na diversidade e composição de espécies de peixes em riachos da bacia do Rio Ivinhema, Alto Rio Paraná. Biota Neotropica, vol. 8, no. 3, pp. 197-204. http://dx.doi.org/10.1590/S1676-06032008000300018.

SÚAREZ, Y.R., SOUZA, M.M., FERREIRA, F.S., PEREIRA, M.J., SILVA, E.A., XIMENES, L.Q.L., AZEVEDO, L.G., MARTINS, O.C. and LIMA-JUNIOR, S.E., 2011. Patterns of species richness and composition of fish assemblages in streams of the Ivinhema River basin, Upper Paraná River. Acta Limnologica Brasiliensia, vol. 23, no. 2, pp. 177-188. http://dx.doi.org/10.1590/S2179975X2011000200008.

SÚAREZ, Y.R., VALÉRIO, S.B., TONDATO, K.K., XIMENES, L.Q.L. and FELIPE, T.R.A., 2007. Determinantes ambientais da ocorrência das espécies de peixes em riachos de cabeceira da bacia do rio Ivinhema, Alto Rio Paraná. Acta Scientiarum. Biological Sciences, vol. 29, no. 2, pp. 145-150. http://dx.doi.org/10.4025/ actascibiolsci.v29i2.520.

TAKAHASHI, E.L.H., ROSA, F.R.T., LANGEANI, F. and NAKAGHI, L.S.O., 2013. Spatial and seasonal patterns in fish assemblage in Córrego Rico, upper Paraná River basin. Neotropical Ichthyology, vol. 11, no. 1, pp. 143-152. http://dx.doi.org/10.1590/S167962252013000100017.

TER BRAAK, C.J.F. and PRENTICE, I.C., 1988. A theory of gradient analysis. Advances in Ecological Research, vol. 18, pp. 271-317. http://dx.doi.org/10.1016/S0065-2504(08)60183-X.

TERESA, F.B. and CASATTI, L., 2010. Importância da vegetação ripária em região intensamente desmatada no sudeste do Brasil: um estudo com peixes de riacho. Pan-American Journal of Aquatic Sciences, vol. 5, no. 3, pp. 444-453.

TERESA, F.B. and CASATTI, L., 2012. Influence of forest cover and mesohabitats types on functional and taxonomic diversity of fish communities in Neotropical lowland streams. Ecology Freshwater Fish, vol. 21, no. 3, pp. 433-442. http://dx.doi. org/10.1111/j.1600-0633.2012.00562.x.

TORGERSEN, C.E. and CLOSE, D.A., 2004. Influence of habitat heterogeneity on the distribution of larval Pacific lamprey (Lampetra tridentata) at two spatial scales. Freshwater Biology, vol. 49, no. 5, pp. 614-630. http://dx.doi.org/10.1111/j.13652427.2004.01215.x.

VIEIRA, D.B. and SHIBATTA, O.A., 2007. Peixes como indicadores da qualidade ambiental do ribeirão Esperança, Município de Londrina, Paraná, Brasil. Biota Neotropica, vol. 7, no. 1, pp. 5765. http://dx.doi.org/10.1590/S1676-06032007000100008.

WEAVER, A.L. and GARMAN, G.C., 1994. Urbanization of a watershed and historical changes in a stream fish assemblage. The American Fisheries Society, vol. 123, no. 2, pp. 162-172. http://dx.doi. org/10.1577/1548-8659(1994)123<0162:UOAWAH>2.3.CO;2.

WHITTAKER, R.H., 1967. Gradient analysis of vegetation. Biological Reviews of the Cambridge Philosophical Society, vol. 42, no. 2, pp. 207-264. http://dx.doi.org/10.1111/j.1469-185X.1967.tb01419.x. PMid:4859903.

WINEMILLER, K.O. and WILLIS, S.C., 2011. The Vaupes Arch and Casiquiare Canal: barriers and passages. In: J. ALBERT. Historical biogeography of neotropical freshwater fishes. Berkeley: University of California Press, pp. 225-242. http://dx.doi.org/10.1525/ california/9780520268685.003.0014. 